\title{
A TEOLOGIA NA Minha CAMinHAdA
}

Theology in My Journey

Luiz Alberto Gómez de Souza *

Começo por agradecer calorosamente a enorme honra que me conferiu Ca congregação da Faculdade Jesuíta de Filosofia e Teologia. Neste momento, me sinto apenas um representante menor de toda uma caminhada coletiva. Não posso também esquecer a enorme generosidade de Leonardo Boff, sugerindo que uma entidade acadêmica me outorgasse o título que agora recebo.

Quero também fazer memória de dois professores desta casa, o filósofo Henrique Cláudio de Lima Vaz e o teólogo João Batista Libanio. Padre Vaz, nos anos 60, foi o grande mestre de minha geração. Falarei dele adiante. É uma alegria poder visitar aqui seu Memorial, com sua extraordinária obra reunida. Padre Libanio foi companheiro em tantas assessorias e cursos que fizemos pelo Brasil afora, descendo o Araguaia, entrando pelo Pará e pelo Acre, numa profunda complementaridade. Ele assumia a perspectiva sociológica, ajudando-me a sistematizar e a precisar o trabalho de Antonio Gramsci e eu, por minha vez, me aventurava pelos caminhos da teologia (GÓMEZ DE SOUZA, 2015).

Tudo o que vou narrar é apenas um sinal minúsculo do muito que representa para mim Lucia, companheira de toda minha vida. Sinto, nestes 59 anos compartidos, que estamos sempre e cada vez mais unidos num renovado amor e numa incrível cumplicidade. Graças a ela, fui me tornando

* Palestra proferida dia 26 de outubro de 2018, por ocasião da recepção do título de Doutor Honoris Causa pela FAJE de Belo Horizonte. 
o que sou. E agora, seguimos juntos, olhando para adiante, com alegria e esperança, soñando caminos de la tarde (MACHADO,1975).

No correr do texto irão se explicitando o bem-querer e a enorme gratidão que me unem a tantas e a tantos.

Abrindo a reflexão, nesta ocasião, gostaria de compartir como a teologia foi entrando no marco de minhas fidelidades.

Tudo começou na equipe nacional da Juventude Universitária Católica (JUC), de 1956 a 1958. Naquela época, não descobríamos no Brasil uma reflexão teológica que respondesse às inquietações do movimento. Fomos buscá-la em autores franceses, no dominicano Yves Congar, com seu alentado Jalons pour une théologie du laïcat (CONGAR, 1953) e no jesuíta Henri de Lubac. Os dois tiveram livros retirados da circulação, depois da encíclica Humani Generis, de Pio XII, em 1950, que bloqueou o desenvolvimento teológico. De Lubac, nos seus tempos de silêncio obsequioso, produziu uma obra, Méditation sur l'Église (DE LUBAC, 1953) que era uma declaração de amor à Igreja que o punira. O livro saiu em 1953 e, em 1957, quatro anos depois, na primeira colaboração com Lucia, minha companheira, traduzimos extratos no Boletim Nacional com o título A Igreja no meio do mundo (JUC, Boletim Nacional, 1/57). Mais adiante, publiquei um texto de Emmanuel Mounier, que seria meu grande guia e que se aventurava nos terrenos teológicos: O temporal, sacramento do Reino de Deus (Ibid., 5/59).

Em 1962, participei de um livro coletivo, Que será o Concílio? (GÓMEZ DE SOUZA; DALE; LIMA; 1962). Minha ideia central era a Igreja em diálogo, entre cristãos e com o mundo moderno. Isso me valeu a rabujice de Gustavo Corção contra os dialogantes, chamando-me de teólogo leigo tropical. Primeiro título que recebi, feliz de contar-me na onda dos tropicalistas. Jovens leigos, talvez um pouco auto-suficientes, dizíamos sorrindo estar en mal de théologie.

A segunda experiência inesquecível foi o trabalho com D. Hélder Câmara, entre 1962 e 1963, nos inícios do Vaticano II. Durante a primeira sessão conciliar, enviei-lhe a Roma um texto: Notas para uma pastoral do desenvolvimento. Eram os tempos do desenvolvimentismo, superados adiante pelo horizonte da libertação. D. Hélder, numa de suas fecundas madrugadas, traduziu-o generosamente ao francês e o fez circular. Na época, recebi incentivo do teólogo dominicano Marie-Dominique Chenu. ${ }^{1}$

No ano seguinte, assessorei D. Hélder entre as duas primeiras sessões do concílio. Com outros padres conciliares, ele temia que o concílio se fechasse numa relação eclesial interna e pedia que saísse de uma visão

${ }^{1}$ Carta de D. Hélder a Luiz Alberto e Lucia desde Roma, 27/28 outubro 1963 (manuscrita, arquivo do autor). 
ad intra, para uma abertura ad extra. Muitos anos depois, Francisco falará de Igreja em saída.

Naquele momento, apareceram os primeiros esquemas conciliares. Ao lado dos que tratavam da Igreja em si mesma, foi acrescentado um novo, esquema XVII, depois esquema XIII, sobre as relações da Igreja com o mundo; ele seria a base da Constituição Pastoral Gaudium et Spes, A Igreja no mundo atual. Dicionário em punho, trabalhei com Lucia Ribeiro e Candido Mendes de Almeida, avançando com certa dificuldade nos enormes parágrafos em latim, língua que não estava preparada para expressar muitos dos problemas contemporâneos. Por exemplo, como falar de informática, ou de células-tronco?

Em 1962, recordo Betinho chegando na minha casa com uma pasta azul, onde reunira artigos do Padre Vaz, de frei Cardonnel, um Manifesto de Estudantes da PUC do Rio e um texto seu, Juventude cristã hoje. Pediu-me para editá-los e eu fiz a introdução. Assim lançamos, Betinho e eu, Cristianismo hoje, pela Editora Universitária da União Nacional dos Estudantes (GÓMEZ DE SOUZA; 1962). Teve ampla difusão no meio universitário e na Frente Nacionalista. A segunda edição estava nos porões da UNE e foi quase toda destruída, quando a entidade foi incendiada em primeiro de abril de 1964.

Nesse momento, começou um profundo encontro com Henrique Cláudio de Lima Vaz, a partir de então a influência intelectual determinante em minha geração. Quando muitos ainda seguiam Jacques Maritain, querendo desenhar dedutivamente um ideal histórico para o Brasil, Padre Vaz reagia: para ele, a tendência a imobilizar os ideais históricos "como essências puras, pode representar uma fuga sutil da história real". Antes indicava: "Prefiro falar de consciência histórica". E precisava:

A consciência histórica de uma determinada época não suscita seus ideais históricos como 'essências realizáveis', mas como imagens e modelos de sua essência efetiva, das suas contradições reais, de seu desdobramento concreto. É a análise deste desdobramento que deve orientar as decisões lúcidas (VAZ, 1962, p. 71).

Trouxe-nos o pensamento de Emmanuel Mounier e de Teilhard de Chardin.

Na celebração dos 70 anos do Padre Vaz eu indicava: o que levou uma geração de estudantes católicos sedentos de ação e de compromisso, presentes na política universitária e, logo depois, na educação popular, a procurar um filósofo difícil, denso e de altos voos teóricos? O que levou aquele filósofo a gastar seu tempo, sempre tão bem administrado e a munir-se de infinita paciência para ouvir e tratar de responder àqueles jovens, sôfregos, entusiastas e imprecisos, sem vocabulário técnico apropriado?... Que solidariedades misteriosas e profundas se pressentiam e se foram constituindo vitalmente, numa intencionalidade nem sempre explí- 
cita, tecendo uma rede de fidelidades e, ousaria dizer, de cumplicidades, criando laços não apenas intelectuais, mas também afetivos... desafiando a contenção jesuítica e o pudor mineiro? (GÓMEZ DE SOUZA, 1991).

Padre Vaz nos descortinou, lúcida e poeticamente, os grandes horizontes da esperança. Como exemplo, o final lírico de um dos seus textos em Cristianismo hoje, citando Emmanuel Mounier: "O pequeno e encolhido medo abriga-se no ancoradouro das tranquilas enseadas do passado, onde os mastros vegetam na calmaria de todos os conformismos. A coragem lúcida e generosa eleva o gesto largo ao vento dos grandes espaços livres, abrindo no mastro grande a grande vela para a rota da mais alta estrela" (VAZ, 1962, p. 87).

Momento importante: já em junho de 1962, no convento dos dominicanos em Belo Horizonte, demos os primeiros passos do que, no ano seguinte, seria a Ação Popular. Com Betinho e outros companheiros, nos lançamos na preparação do movimento. Não queríamos criar uma agrupação de cristãos de esquerda - Mounier nos afastara dessa tentação - mas um movimento plural, com membros de várias origens. A introdução de seu Documento Base indicava "ser a expressão concreta de uma geração que traduz, em ação revolucionária, as opções fundamentais que assumiu como resposta ao desafio de nossa realidade e como decorrência de uma análise realista do processo social brasileiro" (LIMA, 1979). Esse texto foi redigido em Ondina, Salvador, em março de 1963.

Lembro Padre Vaz, no sofá da sala de minha casa, corrigindo cuidadosamente o capítulo filosófico, palavra por palavra. Ali se rejeitavam tanto uma consciência-reflexo, em que o econômico determinava uma realidade como, do outro lado, concepções idealistas. "É, pois, numa perspectiva realista que colocamos, face a face, a consciência e o mundo, o homem e a natureza. Sua articulação é uma articulação dinâmica, dialética" (LIMA, 1979). No centro, a práxis concreta na realidade do Brasil daquele momento. Ficava clara uma opção por um socialismo democrático e humanista.

Saltando no tempo, depois do golpe de 1964, com as limitações de um trabalho clandestino, a Ação Popular tomou outra inflexão, ligando-se ao marxismo-leninismo em voga. Com melancolia nos afastamos, eu já em 1967, Betinho nos anos setenta. Perdeu-se um percurso original.

1963 foi um ano intenso. Trabalhei com D. Helder e, no meio do ano, como assessor do Ministro da Educação Paulo de Tarso; aí recolheríamos e incentivaríamos uma prática de cultura popular que brotava pelo país afora. Vistas agora, essas duas atividades eram profundamente complementares.

Em março de 1964, em tempos conturbados que fazem recordar o atual, nosso querido mestre, Alceu de Amoroso Lima, em longa e afetuosa carta, 
com algumas confidências e muitas preocupações pelo momento político, me escreveu:

Você é um militante, um engajado, e diz muito bem que está no grupo dos que já 'estão preparando o Vaticano III'... Do meu canto... de aposentado... de livre atirador... sinto perfeitamente que o impulso dado por João XXIII ainda não será neste século que se incorporará à Igreja... eu pelo menos, não verei o III. Você talvez [Dr. Alceu tinha na ocasião 71 anos e eu 28; agora tenho quase 83 anos e não vi um novo concílio]. Mas de qualquer modo, eu no meu canto de velho reformado, você na linha de combate, estamos realmente preparando os caminhos para o Cristo do século XXI, como fizeram os 72 discípulos, que ele mandou, 'dois a dois' (GÓMEZ DE SOUZA, 2008, carta).

Essa última menção me tocou fundo, imaginando o mestre avançando valente e eu, tentando segui-lo uns passos atrás. Mal sabia ele que seria uma voz desassombrada nos tempos seguintes. No hoje famoso artigo, Terrorismo cultural, de 7 de maio de 1964, sobre demissões e prisões, refere-se à minha prisão em Belo Horizonte (LIMA, 1999). O texto lhe valeu, inclusive, um telefonema alarmado do presidente militar Castelo Branco (LIMA, 2003).

Ao voltar à liberdade, comecei a escrever um pequeno livro, $O$ cristão $e$ o mundo (GÓMEZ DE SOUZA, 1965). Sempre em meu itinerário regressa a relação permanente religião e sociedade, ou melhor, religião imersa na sociedade e a serviço dela. Ali cito Péguy: "Eis o que os anjos não conhecem... Ter este corpo; ter esta ligação com este corpo; ser este corpo. Ter esta ligação com a terra, ser esta terra, o limo e o pó, a cinza e o lodo. $\mathrm{O}$ próprio corpo de Jesus" (PÉGUY, 1916b). Lembrava um verso de Jorge de Lima: "Não dividamos o mundo. Dividamos o Cristo. Todos ressuscitarão iguais" (LIMA; MENDES, 1935). E ao final, trazia a Carta a Diogneto, escrita entre os anos 190 e 200: "Os cristãos não se distinguem dos outros homens, nem pelo país, língua ou roupas... (porém) o que a alma é no corpo, os cristãos o são no mundo" (MARROU, 1951).

Dom Helder, de Roma, em sua vigília pela madrugada, escrevia diariamente, ao grupo mais próximo, a família de São Joaquim, depois a família mecejanense, narrando o que se passava nos corredores do concílio. Sua secretária, a inesquecível e adorável Cecilinha, em tempos prévios aos computadores, datilografava o texto manuscrito e tirava cópias em papel carbono. Guardo as mesmas com carinho. Aliás, isso tem permitido aos historiadores acompanhar momentos inéditos do concílio. Pois bem, tive a alegria de ver, em duas cartas, o Dom, como dizíamos, ou o padrezinho, comentar no detalhe o meu livro. Que presente melhor eu não poderia ter? Deixando de lado pruridos de modéstia, me atrevo a citar um trecho de uma das cartas:

Se o Luiz escrevesse em francês ou inglês... bem poderia ser o nosso Hans Küng: é o pensamento que me vem ao vê-lo tão identificado com o autor de Concílio e volta à unidade. O que ele é mesmo é o nosso (Emmanuel) Mounier 
e gostaria de ser o nosso (Maurice) Blondel (CÂMARA, 2009, Cartas de 23 e 24/11 e 24 e 25/11).

Ao final do Vaticano II, D. Hélder tinha uma preocupação. O tema do pobre não recebera a atenção merecida do concílio. Este tivera à frente as Igrejas da Europa desenvolvida, com outra problemática. Em 1965, junto com Ivan Illich, sentiu a necessidade de começar a preparar... um Vaticano III. A ideia de um Vaticano III estava do ar desde antes, como se pode ver em minha correspondência com dr. Alceu. Mais tarde, D. Hélder falará de um Jerusalém II, na continuação daquele narrado nos Atos dos Apóstolos (At 15). E pensaram em reunir uma equipe em Cuernavaca, onde Illich criara um centro intercultural. D. Hélder sugeriu meu nome. Aceitei o convite e para lá fui, em 1965, com Lucia e os filhos ainda pequenos. Na verdade, foi sobretudo um debruçar-me sobre a realidade latino-americana conturbada naqueles 19661967, com as mortes de Camilo Torres e de Che Guevara. Em 1966 fui para o Chile, na Escola Latino-Americana de Ciência Política e, a partir de 1969, na Comissão Econômica para a América Latina (CEPAL - ONU).

Em 1968, a conferência episcopal de Medellín seria, de certa maneira, o que D. Hélder sonhara para um novo concílio. Ali estavam os temas do pecado social no ver da realidade, o pobre como sujeito e a libertação como horizonte.

Estive na preparação de Medellín, numa reunião sobre pastoral universitária em Buga, na Colômbia, em 1967. Ali desenvolvi o tema de uma educação libertadora (GÓMEZ DE SOUZA, 1967), na influência do livro de Paulo Freire que líamos em Santiago ainda em provas: Educação como prática da liberdade (FREIRE, 1967).

Vieram aqueles anos fecundos, do que chamei a década gloriosa da Igreja latino-americana, de Medellín, 1968, à reunião do episcopado em Puebla, 1979. Nesta última, convivi com o melhor da teologia latino-americana, assessorando a reunião do lado de fora (GÓMEZ DE SOUZA, 1982). A contribuição dos cientistas sociais foi reunida em livro pelo jesuíta Xabier Gorostiaga (GOROSTIAGA, 1979).

Participei de inúmeras reuniões na América Latina e no Programa de Cooperação Católica Inter-americana (CICOP). Em Nova Iorque, em 1969, apresentei um trabalho, Tensions between modernization and humanization (Inter-american Forum, CICOP Papers) (GÓMEZ DE SOUZA, 1982). Ali eu indicava: "Os piores impérios são os que não se reconhecem como tal... a liberação do escravo é a liberação do amo". O jornalista Hector Borrat comentou a presença de D. Hélder e de Paulo Freire:

Conhecer pela primeira vez estes dois grandes latino-americanos, significa experimentar a formidável capacidade de comunicação que, na Pátria Grande, parece carisma especialmente destinado aos brasileiros; Luiz Alberto Gómez de 
Souza também participa dele. Uma sorte de sabedoria jovial, um entusiasmo vital que se debruça avassalador sobre os outros ... com os tons de voz e o olhar, com as mãos, com todo o corpo; um fabuloso histrionismo a serviço das convicções mais profundas (BORRAT, 1969).

Fui co-organizador da seguinte reunião em Washington, em 1970. Consegui reunir Paulo Freire, Ernani Fiori e Gustavo Gutiérrez. O tema central, conforme o título dos anais: Conscientization for liberation - notar um neologismo na língua inglesa (COLONNESE, 1971). Voltando ao Brasil, ao mesmo tempo que ensinava na pós-graduação da Universidade Federal do Rio de Janeiro, dava cursos pelo país afora para setores populares e agentes de pastoral.

Mas já em 1967, escrevi na revista uruguaia Víspera: “O pós-concílio ou o risco de um gueto narcisista". Para uma teologia e uma prática eclesial na região que despertavam entusiasmo pelo mundo afora, era fácil cair num certo triunfalismo. Poderíamos entrar "num otimismo ingênuo, pelo simples fato de estar mudando, sem ver como esse processo é lento e carregado de complexidades". E prosseguia: "que é o narcisismo senão a tentação de olhar-se a si mesmo e por si mesmo? E o que é o dom senão dar a vida... pelos outros? Aqui está a caridade no extremo oposto do narcisismo" (GOMEZ DE SOUZA, 1976). Com grande alegria vejo Francisco lançar-se contra o narcisismo, para ele uma doença eclesiástica.

O primeiro obstáculo que devemos superar é o narcisismo. É a tentação mais perigosa. Nem tudo começa e termina comigo; posso e devo olhar para além de mim mesmo, até perceber a beleza e a profundidade do mistério que me cerca, da vida que me supera, da fé em Deus que sustenta cada coisa e cada pessoa, também a minha (IHU on-line, 12/12/2016).

E vai além, pois declarou em discurso à Universidade Gregoriana e aos Institutos Consagrados: "Faz muito mal o narcisismo dos teólogos. É disgustoso" (IHU on-line, 14/4/2014).

No texto acima referido, eu assinalava a necessidade de perder-nos no meio dos homens, na sua luta comum. "A salvação do mundo é inseparável da libertação de um terço da humanidade subalimentada" (GÓMEZ DE SOUZA, 1976). Referindo-me ao Brasil, indicava também a relevância do encontro com as religiões afro:

Fala-se de diálogo ecumênico com os irmãos protestantes, mas não existe, no Brasil, um verdadeiro diálogo com nossos irmãos pais de santo [...]. Segue-se com atenção a experiência religiosa de Taizé ou de Chevetogne, e se esquece dos terreiros, nos quais o sagrado, queiram ou não, se expressa na profundidade da alma mestiça brasileira (GÓMEZ DE SOUZA, 1976).

E nessa linha, já em 1967, publiquei um pequeno texto: Saravá, pai de santo, meu irmão. Voltarei adiante a este ponto. 
Com irmãos evangélicos tínhamos um intenso diálogo, não em função de nossas diferenças doutrinárias, mas no encontro comum com os problemas latino-americanos. Era o que chamávamos um ecumenismo na base. Porém era ainda um trabalho entre primos-irmãos. Como ampliá-lo?

E aqui quero fazer uma reparação histórica. Quinze anos antes do surgimento da teologia da libertação, o teólogo presbiteriano Richard Shaull, publicou, em 1953, O cristianismo e a revolução social (SHAULL, 1953), desenvolvendo as bases de uma teologia da revolução, em diálogo com o pensamento marxista. Teve sérios problemas em sua Igreja paulista e deixou o país no começo dos anos 60, voltando para sua universidade em Princeton, onde me recebeu mais adiante. Durante os anos seguintes tive alguns diálogos fecundos com Dick Shaull. Em 2003, em seu último livro, pouco antes de morrer, escreveu: "retorno ao meu ponto de partida de há cinquenta anos,... que desde então significava para mim Igreja em diáspora... me alegra o fato de que o movimento do Espírito não está cerceado nos limites das instituições eclesiásticas" (SHAULL, 2003). Para ele, era evidente a criação de aberturas na descontinuidade das instituições religiosas. Aprendi muito com ele nessa saída do institucional.

Eu estava nos Estados Unidos, em agosto de 1968 e acompanhei a forte rebeldia da juventude, anunciando uma nova era aquariana. Dick Shaull, sempre atento ao novo, seguiu com entusiasmo esse despertar de uma contracultura. No protesto estava implícita a esperança, como na última canção da peça Hair: Let the sunshine in (deixe o brilho do sol entrar).

Voltando ao meu percurso, entre tantos, quero trazer a memória de dois grandes mestres, Gustavo Gutiérrez e Leonardo Boff. Desde 1959 acompanho o itinerário luminoso de Gustavo, irmão maior em sabedoria e graça. Ele nos tem revelado os eixos da caminhada da libertação. Para ele, teologia é uma palavra coerente com uma prática. $\mathrm{O}$ ato primeiro é contemplar e praticar, fazer teologia é ato segundo. O ponto de partida é o encontro com Deus na história através do próximo, iluminado pelo seguimento de Jesus. Indica que os pobres evangelizam e lança repetidamente a grande e dolorosa interrogação: Onde dormem os pobres? (GUTIÉRREZ, 1971, 1979, 1983, 1986).

Em 1975, ouvi Leonardo falar do percurso de uma teologia do cativeiro a uma teologia da libertação (QUIJANO, 1975). Eram os anos de chumbo da realidade brasileira. Nos anos seguintes foi descortinando, profeticamente, um cenário cada vez mais amplo. Da opção pelos pobres à opção pelo planeta terra. Título de um de seus livros: Ecologia, grito da terra, grito do pobre (BOFF, 1995). Indica a necessidade de saber cuidar, do pobre ao planeta ferido (BOFF, 2008). Traz o desvelo pela mãe terra, Gaia, Pachamama (BOFF, 2010). Ligado ao grande movimento ecológico internacional e sendo um de seus porta-vozes, Leonardo participou ativamente na elaboração da Carta da Terra, finalizada em 2000. 
Junto a estes dois mestres, quero incluir a presença instigadora de meu irmão Marcelo Barros. Gustavo falava de beber no próprio poço de vida espiritual. Por anos me alimentei no espaço privilegiado do Mosteiro da Anunciação em Goiás, onde Marcelo me acolhia (BARROS, 1992, 1998, 2008). Hoje ele exerce sua missão profética pelo mundo afora (BARROS, 1994).

$\mathrm{Na}$ atualidade, um momento decisivo é o diálogo inter-religioso, seguindo a reflexão luzente de Thomas Merton. Este, da Trapa de Getsêmani, abriu-se sempre mais aos temas sociais candentes de seu tempo e a outras tradições religiosas, em especial o zen-budismo. Ansiava por "um amor que seja contemplação e ação, que se apegue a Deus e abrace, n'Ele, o mundo todo, em paz, em unidade" (MERTON, 2006).

O diálogo inter-religioso poderia ficar num debate doutrinário abstrato, se não fosse referido a uma situação social concreta. Macro-ecumenismo, para Pedro Casaldáliga, teria de estar ancorado num compromisso com a vida e com a justiça (CASALDÁLIGA; VIGIL, 1996).

Nessa linha, dia 7 de julho deste ano, Francisco se reuniu com patriarcas e mais de trinta Igrejas cristãs em Bari, às margens do Adriático. Foi um momento para refletir e rezar pelo sofrimento dos cristãos na região em frente, o Oriente Médio. A Igreja Caldéia, por exemplo, está especialmente vulnerável. Francisco referiu-se a um ecumenismo de sangue (IHU on-line, 2/7/2018; 8/7/2018). Recentemente, lembrou também uma observação curiosa do Patriarca Atenágoras a Paulo VI. No seu estilo cortante e surpreendente, Atenágoras lançou esta boutade: "Façamos a unidade entre nós e mandemos todos os teólogos para uma ilha, para que pensem" (IHU on-line, 23/1/2018).

Com o atual Patriarca Ecumênico Bartolomeu, Francisco esteve em Lesbos, em abril de 2016, para acolher milhares de imigrantes que chegavam. E denunciou o homicídio da indiferença (IHU on-line, 18/4/2016). Já logo depois de ser eleito bispo de Roma, em julho de 2013, tinha estado em Lampedusa, e ali recordou, com tantos refugiados muçulmanos, que estavam no tempo de Ramadã (IHU on-line, 7/7/2013).

O encontro entre Cristianismo e Islã levou, em alguns casos, à perseguição e ao martírio. Há cinco anos desapareceu na Síria o Padre Paolo Dall'Oglio que fundara o Mosteiro Deir Mar Musa para um encontro entre cristãos e muçulmanos (IHU on-line, 1/8/2018). Na Argélia, o Mosteiro de Tibhirine tinha a mesma vocação. Sete dos seus monges foram mortos em 1996, assim como o bispo de Oran, mártires do amor, como proclamaram os bispos franceses (IHU on-line, 4/4/2016; 25/5/2016). Ver o filme de Xavier Beauvois, Homens e deuses (2010).

Não podemos esquecer que a perseguição também se estende a outras minorias não cristãs. Na Síria e no Iraque os yájidis, comunidade étnico-religiosa curda, com religião pre-islâmica; em Myanmar (Birmânia) os royingyas, islâmicos são perseguidos por budistas intolerantes. 
E aqui quero introduzir o tema dos mártires latino-americanos, onde a perseguição aos cristãos se dá por razões sócio-políticas. Escrevi sobre São Romero da América, a quem encontrei por duas vezes, na reunião episcopal de Puebla, em 1979 e meses depois em San Salvador. Guardo suas palavras, quando lhe perguntei como se movia em situação tão crítica: "Tudo o que tenho a fazer é tentar interpretar meu povo e ser fiel a ele". Nada tão terrivelmente simples e difícil. Até hoje ecoa o chamado lancinante em seu último sermão: "Em nome de Deus, em nome deste povo sofrido, cujos lamentos sobem até o céu cada dia mais fortes, lhes suplico, lhes rogo, lhes ordeno: cessem a repressão". No dia seguinte seria morto quando, na celebração eucarística, oferecia o vinho que ia tornar-se sangue do Senhor (GÓMEZ DE SOUZA, 1980). Dia 14 de outubro, Francisco o elevou aos altares. Mas para a consciência cristã da Igreja salvadorenha, desde 1980 já era santo e mártir. Foi proclamado por um povo de Deus eclesialmente ativo, pelo sensus fidelium, como ensinaram John H. Newman e Yves Congar (GÓMEZ DE SOUZA, 2018).

"Deus passou por El Salvador", testemunhou o filósofo jesuíta Ignacio Ellacuría (IHU on-line, 28/7/2014). Logo depois, em 1989, o próprio Ignacio e cinco companheiros, com uma funcionária e a filha, foram trucidados por um esquadrão da morte (IHU on-line, 16/11/2009). Jon Sobrino, teólogo notável, que escapou de morrer por estar ausente do país, tem escrito páginas memoráveis sobre os mártires, no seguimento de Jesus (SOBRINO, 1988; 1999). Francisco o acolheu efusivo na canonização de Oscar Romero (IHU on-line, 18/10/2018).

Longa é a lista dos mártires da região: o operário Santos Dias, a líder camponesa Margarida Alves, o bispo argentino Enrique Angelelli e tantos mais. Lembro quando, na reunião das CEBs em Trindade, 1996, a mãe do Padre Josimo Tavares trouxe sua camisa ensanguentada.

Em 1964, D. Hélder sentiu dolorosamente que a tortura e a morte do Padre Henrique Pereira Neto estavam dirigidas a ele. Também, em 1976, Pedro Casaldáliga teve o mesmo sentimento no assassinato do padre João Bosco Penido Burnier.

Voltando ao diálogo inter-religioso, recordo aquela vigília, ao final do encontro Rio 92 - Cúpula da terra. Na luz tênue do amanhecer chegaram Dom Hélder Câmara e o Dalai Lama, com suas mensagens de paz e de harmonia. Ali ao lado, na tenda do Santo Daime, ouvia-se o bailado contagiante dos seus hinos. Tantos caminhos confluíam numa mesma direção de transcendência espiritual.

Ernesto Cardenal, em seu Cántico Cósmico, denunciou a tentação de todas as culturas e crenças de se sentirem o centro, o onfalos, o umbigo. E lembra uma fonte sânscrita: "Morada de todos, em todos habita. Unidade e diversidade: Como uma única lua se reflete em muitas fontes (poços de água viva)" (CARDENAL, 1993). 
O Padre Ernesto Balducci, em seu instigante livro, L'uomo planetario, se interroga:

Se a humanidade deve enfrentar o futuro como um sujeito único, onde encontrará agora o princípio unificador da própria consciência? E responde: As primeiras testemunhas da unidade do gênero humano são os místicos; diante deles, um filósofo como Hegel, é apenas um pensador genial da tribo prussiana (BALDUCCI, 2005).

Graças ao notável trabalho de Faustino Teixeira, teólogo leigo, podemos acompanhar o encontro dos místicos, de Rûmî ou de Ibn al'Arabī, no século XIII, a Teresa de Jesus e João da Cruz no século XVI. Eles não se aprisionaram nas instituições religiosas. Cito Rûmî/Nevlana: "Não sou cristão, nem judeu, nem mago, nem muçulmano, não sou do Oriente nem do Ocidente... deixei de lado a dualidade, vejo os mundos num só". (LUCCHESI, TEIXEIRA, 2007). E Ibn al'Arabī: "Assim é o homem universal, que leva a semente de todos os seres" (ARABÍ, 2002). Descobrimos como nos antigos livros vedas, no sufismo islâmico, no chassidismo hebreu, no hinduísmo, nas várias correntes do budismo, nos místicos cristãos, pulsa uma mesma linguagem de busca.

Para Balducci, Jesus na cruz perdeu todas as determinações: "não era mais nem de raça semítica, nem hebreu, nem filho de Davi. Era universal". E traz uma conclusão surpreendente: "Esta é minha profissão de fé: [...] quem ainda se declara ateu, ou marxista ou laico e necessita um cristão para completar a série de representantes no palco da cultura, não me procure. Sou apenas um homem" (BALDUCCI, 2005, p. 201).

Fui sentindo, aos poucos, que o mundo das religiões ia ficando estreito. Em trabalho de 1986, num congresso latino-americano de sociologia, eu falava de Secularização em crise e potencialidade transformadora do sagrado (GÓMEZ DE SOUZA, 2003). Esta última categoria me parecia, mais englobante. Na linha de Rudolf Otto, trata-se do numinoso (tradução literal: nume+nous, carregado de divindade). São os caminhos insondáveis do mysterium tremendum (OTTO, 1985). Ortega y Gasset falava das ultimidades (GASSET, 1958). Permito-me uma lembrança sentimental: quando terminei o curso médio, em 1953, com 18 anos, escolhi como lema uma sentença de Gilbert K. Chesterton, autor que eu estava descobrindo com entusiasmo: "O mistério é a saúde do espírito" (CHESTERTON, 1908).

O pessimismo imobilizador de um pensamento pós-moderno descreve um mundo desconexo, líquido e sem rumo. Na tradição das grandes religiões há, entretanto, um sentido na história. Teilhard de Chardin falava de uma direção axial rumo a um ponto ômega (TEILHARD DE CHARDIN, 1966). Na frente, a recapitulação de Paulo (Ef 1, 10).

Observando com cuidado o que se está gestando no underground da história, ao lado de práticas sociais fecundas, descobrimos um enorme revival de 
crenças e de experiências espirituais. No mundo católico temos as práticas das pastorais sociais, das CEBs e de tantos grupos de oração e celebração. Somam-se a tradição da ayahuasca, que vem do Império Inca e se abre em tantas linhas, como o Santo Daime ou a União do Vegetal; a sabedoria dos xamãs, de tradições indígenas na Amazônia que hoje abrem seu legado e conhecimento ao mundo; as experiências dos peioteiros - que utilizam a planta peiote - com vertentes importantes como Camino Rojo no México ou a Igreja Nativa Americana nos Estados Unidos; a força misteriosa das plantas de poder. E se abrem sempre novos e revigorantes caminhos espirituais.

Para a cultura dominante brasileira, que guarda até agora resquícios escravagistas, é indispensável um diálogo com as tradições dos orixás, no candomblé e na umbanda. O sacerdote francês François de l'Épinay, companheiro em Cuernavaca, mergulhou fundo nos terreiros baianos e descreveu sua experiência: A religião dos orixás, outra palavra do Deus único? (DE L'ÉPINAY, 1987). Uma yalorixá declarou, neste 20 de outubro, diante da terrível pregação de uma política de violência: "A gente não vai se esconder, a gente não vai abrir mão de nossa fé, daquilo que conquistamos" (IHU on-line, 20/10/2018).

Temos vivido, Lucia e eu, a experiência concreta do pluralismo religioso na nossa própria família, com a adesão de filhos e netos ao Santo Daime. Ao contrário do que alguns poderiam imaginar, os laços afetivos com nossos filhos, Sílvia, Fernando e Flávio e as noras Antônia e Eunice saem reforçados e sólidos. Além disso, sentimos orgulho de ver os cinco netos, Estêvão, Elias, Francisco Oromi, João e Pedro e a linda neta espanhola, Elisa, crescendo em diversos caminhos criativos e alguns desenvolvendo fortes experiências espirituais. Todos unidos na mesma direção fundamental. Compartimos momentos de intensa cumplicidade e solidariedade, como no caso da apreensão, em 2000, da ayahuasca na Espanha e da prisão de meu filho Fernando, narrados por ele em seu excelente livro Os incas, as plantas de poder e um tribunal espanhol (RIBEIRO, 2005), primeiro de uma trilogia.

Quixote, meu herói, lembrava uma idade de ouro: "eran, en aquella santa edad, todas las cosas comunes, todo era paz entonces, todo amistad y concordia". ${ }^{2}$ Invertendo o sentido, poderíamos ver essa utopia não no passado, mas num horizonte futuro. Nesse sentido, escrevi em livro de 2003: A utopia não estará surgindo no meio de nós? (GÓMEZ DE SOUZA, 2003). Na base da sociedade encontramos um sem número de experiências portadoras de futuro. Talvez frágeis, incipientes, porém com um poder irradiante. São as minorias abraâmicas que assinalou D. Hélder. E na linha do que indicaram os Foros Sociais Mundiais, podemos continuar afirmando que “um outro mundo é possível” (GÓMEZ DE SOUZA, 2003).

${ }^{2}$ Miguel de Cervantes, Don Quijote de la Mancha, 1605, II parte, cap. 11. 
Lembro um encontro, no convento dos dominicanos em Santiago, em 1971 ou 1972, com o já idoso Padre Congar. Perguntei como a teologia poderia ajudar a desvelar os sinais dos tempos na complexa experiência chilena. Respondeu vagarosamente: "a teologia europeia não tem nada a dizer, como numa situação de vacatio legis. São vocês que têm de realizar um discernimento da realidade". No Brasil, há 30 anos, teólogos e cientistas sociais nos reunimos regularmente, o Grupo Emaús, para analisar o contexto social e eclesial. Além disso, militantes na política, acompanhados por teólogos e sociólogos, se encontram em plano nacional e local para refletir sobre Fé e Política, com coordenação de Pedro Ribeiro de Oliveira e sua esposa Tereza Sartório.

Em 2007, o reitor Candido Mendes - companheiro de tantas aventuras -, criou um Programa de Estudos Avançados em Ciência e Religião na Universidade Cândido Mendes (UCAM) e imediatamente me convidou para dirigi-lo. Nesses pouco mais de dez anos, organizei dezenas de seminários sobre os mais diferentes temas da atualidade. Trago alguns exemplos, com palestrantes nacionais e do exterior. $\mathrm{Na}$ área teológica, participaram Leonardo Boff, Hans Küng (Tübingen), Vito Mancuso (Padova), Marcelo Barros, Tereza Cavalcanti. Para a temática de secularização, foram convidados Jose Casanova (Georgetown Univ.) e Charles Taylor (McGill Univ. no Canadá). Para o debate inter-religioso vieram Juan Masiá (Universidade de Sofia, Tóquio), Edson Fernando de Almeida, Fernando Ribeiro, Beatriz Bissio, professores da Universidade de Xangai. Para mística, Maria Clara Bingemer, Faustino Teixeira, Marco Lucchesi. As mesas-redondas eram abertas por Candido Mendes e eu tinha a finalização. Reunimos professores, alunos, profissionais, agentes de movimentos sociais e pastorais (GÓMEZ DE SOUZA, 2015).

Quem viveu 1964 aqui e 1973 no Chile, vê com temor sinais preocupantes no caminho da liberdade. Não foi possível afastar tempos sombrios, nas últimas eleições. Porém, olhando adiante, numa ação na base da sociedade, há que trabalhar na construção de uma Frente Ampla, Democrática e Nacional (IHU on-line, 29/10/2018).

Nesse sentido, é preciso guardar a Esperança, a pequena virtude que, para Péguy, leva pela mão as duas irmãs maiores, a Fé e a Caridade (PÉGUY, 1916a). É esta esperança que anima a grande roda de amizade e de fraternidade que nos cerca, e que se concretizou na publicação que Lucia carinhosamente preparou (RIBEIRO, 2015). No fundo do meu coração, esta ciranda de energia pulsa viva, acompanhando este andarilho em suas andanças. Sinto de maneira particular, neste momento, a presença de meu pai, um não crente que ensinou, a mim e a meus irmãos, a aposta na justiça social.

Concluindo, na linha do poema de John Donne, que Merton põe no título de um de seus livros, Homem algum é uma ilha (MERTON, 1958). "Cada 
homem é uma partícula do continente, uma parte da terra". ${ }^{3}$ Goethe traduziu o logos do Evangelho de João: "No princípio era a ação". Já o teólogo Vito Mancuso dirá com mais propriedade: "No princípio era a relação", isto é, a abertura ao outro/outra (MANCUSO, 2012). É o eu-tu, na alteridade de Martin Buber (BUBER, 1996).

Nesse sentido, teologia se faria antropologia, enraizada no cotidiano relacional das pessoas e das comunidades. Fazer teologia fecunda pode ser comprometer-se com a vida, com os outros, com o planeta terra. Na base, não propriamente uma ortodoxia paralisante, mas uma ortopráxis valente, solidária, instigante e renovadora.

\section{Referências}

ARABÍ, I. A alquimia da felicidade. São Paulo: Landy, 2002.

BALDUCCI, E. L'uomo planetario. Florença: Giunti, 2005.

BARROS, M. Celebrar o Deus da vida. São Paulo: Loyola. 1992.

. Lettere di um Mónaco tra i poveri. Assis: Rocco. 1994.

. Os pobres possuirão a terra. Salvador: CESE, 1998.

. O espírito vem pelas águas. São Paulo: Loyola, 2008.

BOFF, L. Ecologia, grito da terra, grito dos pobres. São Paulo: Ática, 1995.

. Ecologia, mundialização e espiritualidade. São Paulo: Record, 2008.

. Cuidar da terra, proteger a vida. São Paulo: Record, 2010.

BORRAT, H. En las rutas de Medellín. Marcha, Montevidéu, n. 1436, 1969.

BUBER, M. I and Thou. Cambridge: Touchstone Book, 1996.

CARDENAL, E. Cántico cósmico. Madri: Trotta, 1993.

CASALDÁLIGA, P.; VIGIL, J. M. Espiritualidade de libertação. Petrópolis: Vozes, 1996.

CERVANTES, M. Don Quijote de la Mancha (1605). Universidad de Salamanca: Santillana, 2011.

CHESTERTON, G. K. Ortodoxy. Londres: John Lane, 1908.

COLONNESE, L. Conscientization for liberation. Washington: Division for Latin America, US Catholic Conference, 1971.

\footnotetext{
${ }^{3}$ John Donne, poeta inglês do século XVI: "Nenhum homem é uma ilha isolada; cada homem é uma partícula do continente, uma parte da terra; se um torrão é arrastado para o mar, a Europa fica diminuída, como se fosse um promontório, como se fosse a casa dos teus amigos ou a tua própria; a morte de qualquer homem diminui-me, porque sou parte do gênero humano. E por isso não perguntes por quem os sinos dobram; eles dobram por ti".
} 
CONGAR, Y. Jalons pour une théologie du laïcat. Paris: Cerf, 1953.

DE L'ÉPINAY, F. A religião dos orixás, outra palavra do Deus único? Revista Eclesiástica Brasileira, Petrópolis, v. 47, n. 187, p. 639-650, set. 1987.

DE LUBAC, H. Méditation sur l'Église. Paris: Cerf, 1953.

FREIRE, P. A educação como prática da liberdade. Rio de Janeiro: Paz e Terra, 1967.

GASSET, J. O. y. El hombre y la gente. Madri: Revista Occidente, 1958.

GÓMEZ DE SOUZA, L. A.; DALE, R.; LIMA, D. Que será o concílio? Rio de Janeiro: D. Bosco, 1962.

; SOUZA, H. J. de. Cristianismo hoje. Rio de Janeiro: Universitária, 1962.

. O cristão e o mundo. Petrópolis: Vozes, 1965.

. Problemática de la educación en América Latina. Educación no 2. Bogotá: CELAM, 1967.

El pos-concilio y el riesgo de un gueto narcisista. Víspera, Montevideu, ano 1 n. 1, 1976.

D. Oscar Romero. A fé imersa no conflito político. Tempo e Presença, Rio de Janeiro, n. 26, 1980.

. Classes populares e Igreja nos caminhos da história. Petrópolis: Vozes, 1982.

. Pe. Vaz, mestre de uma geração de cristãos. Síntese, Belo Horizonte, v. 18, n. 55, out./dez. 1991.

. A utopia surgindo no meio de nós. Rio de Janeiro: Mauad, 2003.

- Uma fé exigente, uma política realista. Rio de Janeiro: Educam, 2008.

. Um andarilho entre duas fidelidades: religião e sociedade. Rio de Janeiro:

Ponteio/ Educam , 2015.

Oscar Romero, santo na consciência latino-americana desde 1980. Rio de Janeiro:

Carta Maior 15/10, 2018.

GOROSTIAGA, X. (Ed.). Para conocer América Latina. Panamá: Ceasma; San José: Educa, 1979.

GUTIÉRREZ, G. Teología de la liberación: perspectivas. Lima: Cep, 1971.

. La fuerza histórica de los pobres. Lima: Cep, 1979.

- Beber en su próprio pozo: el itinerário de un pueblo. Lima: Cep, 1983.

. Hablar de Dios desde el sufrimiento del inocente, una reflexión desde el libro de Job. Lima: Cep, 1986.

LIMA, A. A. Revolução, reação ou reforma. Petrópolis: Vozes, 1999.

Cartas ao pai. Rio de Janeiro: Instituto Moreira Sales, 2003.

LIMA, J. de; MENDES, M. O tempo e a eternidade. Porto Alegre: Globo, 1935.

LIMA, L. G. de S. Evolução política dos católicos e da Igreja no Brasil. Petrópolis: Vozes, 1979. 
LUCCHESI, M.; TEIXEIRA, F. O canto da unidade: em torno da poética de Rumi. Rio de Janeiro: Fissus, 2007.

MACHADO, A. Soledades (1902), Barcelona: Labor, 1975.

MANCUSO, V. Obbedienza e libertà: Critica e rinnovamento della coscienza cristiana. Roma: Fazi, 2012.

MARROU, H.-I. (ed.) Lettre à Diognète. Paris: Cerf, 1951. (Sources chrétiennes).

MERTON, T. Homem algum é uma ilha. Rio de Janeiro: Agir, 1958.

. Místicos e mestres zen. São Paulo: Martins Fontes, 2006.

OTTO, R. O sagrado. São Paulo: Imprensa metodista, 1985.

PÉGUY, Ch. Oeuvres complètes. Le porche du mystère de la deuxième vertu. Paris: Nouvelle Revue Française, 1916a. v. 5.

1916b. v. 6.

Oeuvres complètes. Oeuvres de poésie. Paris: Nouvelle Revue Française,

QUIJANO, F. Liberación y cautiverio. Debates en torno al método de la teología de la liberación en América Latina. México: Anais do encontro, 1975.

RIBEIRO, F. Os incas, as plantas de poder e um tribunal espanhol. Rio de Janeiro: Mauad, 2005.

RIBEIRO, L. A roda da amizade. Edição privada, 2015.

SHAULL, R. O cristianismo e a revolução social. São Paulo: Uceb, 1953. Surpreendido pela graça: memórias de um teólogo. São Paulo: Record, 2003.

SOBRINO, J. Profeta e mártir da libertação. São Paulo: Loyola, 1988.

. La fé en Jesucristo: ensayo desde las víctimas. Madri: Trotta, 1999.

TEILHARD CHARDIN, P. O fenômeno humano. São Paulo: Herder, 1966.

VAZ, Henrique C. de Lima. O cristianismo na direção axial da história do pequeno mundo antigo à aventura cósmica. In. GOMEZ DE SOUZA, L. A; SOUZA, H. J. de. Cristianismo hoje. Rio de Janeiro: Universitária, 1962. p. 69-82.

Luiz Alberto Gómez de Souza é doutor em Sociologia pela Sorbonne Nouvelle, Paris III, mestre em Ciência Política pela Escuela Latinoamericana de Ciencia Política, Santiago do Chile. Secretário Geral da Juventude Estudantil Católica Internacional (Paris, 1959-1961). Funcionário internacional da ONU: CEPAL (1969-1977) e FAO (1983-1985). Diretor do Programa de Estudos Avançados em Ciência e Religião, Universidade Cândido Mendes (2007-2017). E-mail: gomezdesouza@uol.com.br

Endereço: Rua das Laranjeiras 525, apartamento 1002 22240-005 Rio de Janeiro - RJ 